*** Pre-print draft of paper forthcoming in European Journal of Philosophy ***

\title{
Schopenhauer on the Rights of Animals
}

\author{
Stephen Puryear \\ North Carolina State University
}

\begin{abstract}
I argue that Schopenhauer's ascription of (moral) rights to animals flows naturally from his distinctive analysis of the concept of a right. In contrast to those who regard rights as fundamental and then cast wrongdoing as a matter of violating rights, he takes wrong (Unrecht) to be the more fundamental notion and defines the concept of a right (Recht) in its terms. He then offers an account of wrongdoing which makes it plausible to suppose that at least many animals can be wronged and thus, by extension, have rights. The result, I argue, is a perspective on the nature of moral rights in general, and the idea of animal rights in particular, that constitutes an important and plausible alternative to the more familiar views advanced by philosophers in recent decades.
\end{abstract}

\section{Introduction}

Schopenhauer stands as one of the first Western philosophers to accord not only moral standing but moral rights to animals. ${ }^{1}$ On the negative side, he denounces the view that they lack such rights as 'a revolting crudity and barbarism of the West' (BM 238) and, in the case of Spinoza, an 'absurd and abhorrent' aspect of the latter's contempt for animals (WWR 2:739). ${ }^{2}$ On the positive side, he notes with approval that 'in

1. The first to do so may have been Rousseau (1755/1992: 14): '[S]ince [animals] share to some extent in our nature by virtue of the sentient quality with which they are endowed, one will judge that they should also participate in natural right, and that man is subject to some sort of duties toward them. It seems, in effect, that if I am obliged not to do any harm to my fellow man, it is less because he is a rational being than because he is a sentient being: a quality that, since it is common to both animals and men, should at least give the former the right not to be needlessly mistreated by the latter'.

2. See also FR 98; PP 2:370-71, 376/SW 6:394, 400. I employ the following abbreviations in citations of Schopenhauer's works: BM: 'On the Basis of Morality', in D. E. Cartwright and E. E. Erdmann (eds.) The Two Fundamental Problems of Ethics, New York: Oxford University Press, 2010, cited by page number from SW 4; FR: 'On the Fourfold Root of the Principle of Sufficient Reason', in D. E. Cartwright, E. E. Erdmann, and C. Janaway (eds.) On the Fourfold Root of the Principle of Sufficient Reason and Other Writings, New York: 
Europe a sense of the rights of animals is gradually awakening in proportion to the fading and vanishing of the strange idea that the animal world was brought into being merely for humans' use and amusement, as a result of which animals are treated just like things' (BM 243). Despite the popularity of this topic in recent times, however, relatively little attention has been paid to the details of Schopenhauer's account. ${ }^{3}$ He clearly wants to ascribe rights to animals. Yet he does not present a theory of animal rights as such. He does offer an analysis of the concept of a right. But he never fully connects the dots between this analysis and his belief in animal rights. Nor does he fully articulate all the relevant features of that analysis. The question therefore arises whether his belief in animal rights has a sound basis.

In what follows, I offer a reconstruction of Schopenhauer's distinctive analysis of the concept of a right, and argue that his ascription of rights to animals flows naturally from this analysis. In contrast to those who regard rights as fundamental and then cast wrongdoing as a matter of violating rights, he takes wrong (Unrecht) to be the more fundamental notion and defines the concept of a right (Recht) in its terms. He then offers an account of wrongdoing which makes it reasonable to suppose that at least many animals can be wronged and thus, by extension, have rights. The result, or so I argue, is a perspective on the nature of moral rights in general, and the idea of animal rights in particular, that constitutes an important and

Cambridge University Press, 2012, cited by page number from SW 1; PP: Parerga and Paralipomena, E. F. J. Payne (ed.) Oxford: Clarendon Press, 1974, cited by volume and page number; SW: Sämtliche Werke, A. Hübscher (ed.) Mannheim: F. A. Brockhaus, 1988, cited by volume and/or page number; WN: 'On the Will in Nature', in D. E. Cartwright, E. E. Erdmann, and C. Janaway (eds.) On the Fourfold Root of the Principle of Sufficient Reason and Other Writings, New York: Cambridge University Press, 2012, cited by page number from SW 4; WWR 1: The World as Will and Representation, J. Norman, A. Welchman, and C. Janaway (eds.) New York: Cambridge University Press, 2010, cited by page number from SW 2; WWR 2: The World as Will and Presentation, D. Carus and R. E. Aquila (eds.) Upper Saddle River: Prentice-Hall, cited by page number from SW 3. Unless otherwise noted, I use the cited English translation, though with occasional modifications.

3. For other discussions of Schopenhauer's animal ethics, which focus mostly on other aspects of his view, see Jones 1991, Brosow 2008, Gebert 2008, and Haucke 2008. 
plausible alternative to the more familiar views advanced by philosophers in recent decades.

My reconstruction begins with Schopenhauer's conception of wrong. I first characterize the central idea (\$2) and then take account of two important complications: the significance of motive (\$3) and the idea that moral beings possess clarity of consciousness in differing degrees (§4). I then introduce his conception of rights and argue that he recognizes two basic kinds of them: those which express what the right-holder can do without wronging others (roughly: liberties) and those which express what others cannot do or fail to do without wronging the right-holder (roughly: claims) (\$5). ${ }^{4}$ Turning to animals, I next argue that Schopenhauer's understanding of rights, together with the plausible assumption that at least many animals have will in the relevant sense, entails that at least many animals have rights of the second sort, if not also the first, and that some may even have special rights beyond these (\$6). Finally, I conclude with some reflections on the philosophical significance of this approach, particularly in relation to recent work in this area (\$7).

\section{Wrongdoing: The Basic Idea}

Despite the lexical priority Recht enjoys over Unrecht, Schopenhauer maintains that the idea of wrong is genetically prior to that of right. In the beginning, the thought goes, people noticed that they were subject to being wronged by others, which led to the idea of actions that are right, that is, which can be performed without wronging others. The idea of right action then eventually led to the idea of a right, something an individual $A$ can possess which expresses either what $A$ can do without wronging others or what others cannot do or neglect to do without wronging $A$. In order to understand the concept of a right in its proper historical sense, then, we must first ask what it means for an action to be wrong, or in other words, what it means to wrong someone.

Schopenhauer sometimes attempts to elucidate the concept of wrong by noting that on his view, Unrecht is synonymous with Verletzung or the Latin laesio, that is, harm or injury (BM 216-19; PP 2:241/SW 6:257). At least for us, however, this observation offers little insight, since the concept of injury stands as much in need of elucidation as that of wrong. A more helpful line of thought developed by Schopenhauer rests on the

4. This distinction was first explicitly drawn, in relation to legal rights, by Hohfeld (1919), though what I call 'liberties' he refers to as 'privileges'. For a helpful discussion of this terminology, see Jones 1994: 12-22. 
idea that to wrong someone is fundamentally to encroach on the territory of that individual's will. What this means, expressed less metaphorically, is that one individual wrongs another when the former acts in a way that prevents the latter's will from attaining its object. This happens in the first instance when an individual thwarts the will of another through some kind of violence or coercion. So if $A$ restrains, assaults, or kills $B$, then $A$ interferes with $B^{\prime}$ s will and thus wrongs $B$. But it also happens, more subtly but no less perniciously, when through cunning or deceit one is made to serve another's will rather than one's own (WWR 1:398-99).

Considered in itself, a will's boundary extends as far as the body in which it manifests itself, since for Schopenhauer the body is just an objectification of the individual's will (WWR 1:119-20). Hence, to the extent that I manipulate or otherwise do violence to the body of another, I wrong that individual. Likewise, the mind itself is an objectification of that will. So to manipulate someone's mind, as in cases of deception, or to cause them mental pain or emotional distress, would also be to impede their will and thus to wrong them. The will's scope therefore includes both the mind and the body. But it does not stop there. For it also extends so far as to encompass any property or possessions that might be acquired by the individual. This happens, according to Schopenhauer, through a kind of labor-mixing, whereby through its force or work the laborer's body 'grows together with' and as it were becomes identified with the object (WWR 1:396). Further, he allows that the will's scope grows so as to include any honor acquired by the individual (BM 219; PP 2:241/SW 6:257). We may therefore say that on his view, $A$ thwarts the will of $B$, and thus wrongs $B$, not only when $A$ harms or manipulates $B^{\prime}$ s mind or body, but also when $A$ takes or damages $B^{\prime}$ s property or in some way diminishes $B^{\prime}$ s honor.

This gives us the basic idea of Schopenhauer's account of wrong. In order to complete the picture, we must now take note of two important nuances. The first has to do with motive, the second with differences in degree of consciousness. ${ }^{5}$

\section{Motive}

An important objection to the account as I have presented it so far is that it is not always wrong to impede the will of another. In the first place, we interfere with other wills whenever we act in self-defense. Yet we do not

5. For other expositions of Schopenhauer's account of wrong, see Copleston 1947: 161-66; Jacquette 2005: 224-28; Jordan 2010: 171-73. 
thereby wrong the aggressor. Furthermore, we sometimes infringe on the territory of another's will by accident, for example, when we inadvertently injure them or damage their property. As long as these acts do not result from negligence, they too would seem to involve no wrongdoing. Being an infringement therefore appears to be at best only a necessary and not a sufficient condition for being a wronging. In order for Schopenhauer's account to be plausible, then, he needs to explain what distinguishes those infringements which are wrongings from those which are not.

One thought Schopenhauer deploys in addressing the case of selfdefense is that, in turning back an aggressor through violence or cunning, I am not, properly speaking, encroaching on the territory of another's will, but merely evicting that will, as it were, from my own territory:

This is because everything that happens on my side falls exclusively within the sphere of the affirmation of will that is essential to my person as such and is already expressed in it (this being the scene of the struggle), and does not encroach into that of the other, and is consequently only the negation of the negation, which is to say an affirmation that is not itself a negation. Thus without doing wrong, I can compel the other will to abstain from its negation of my will as this appears in my body, without negating any other will that observes a similar limitation. (WWR 1:401)

From this perspective, the one who defends herself is like a landowner who forces a trespasser off her property. By encroaching on the landowner's property, the trespasser in a way negates the former's will. But by negating this negation, by pushing the trespasser back, the landowner does not trespass on the other's property; she simply stops him from trespassing on hers. She therefore does no wrong.

The kind of case Schopenhauer has in mind in this passage is one in which an individual defends herself merely by resisting or beating back the attack of another, without thereby harming the other's body, person, property, or honor. But while some instances of justifiable self-defense do seem to fit this pattern-the case of the landowner who removes the trespasser from her property would be one-many do not. In fact, Schopenhauer himself admits that legitimate self-defense may even go so far as to take the life of one's attacker (WWR 1:401), and we would be hard-pressed to spin this as anything but encroaching on the territory of another will. In order to explain why self-defense is not in general wrong, then, we need something more. 
I believe this something more can be found in Schopenhauer's idea that we wrong someone just in case our denial of that individual's will flows from a certain motive. As he explains in his primary discussion of the topic, when an individual wards off some attempted wrong through violent means, 'this resistance cannot itself be wrong [...] even if it involves an act of violence that would have been wrong on its own, taken out of context, and is only justified here by its motive [Motiv], i.e., it becomes right' (WWR 1:400, emphasis mine). In characterizing the violent response to an attack as in itself wrong, Schopenhauer appears to acknowledge that self-defense often if not always involves infringing on the territory of the aggressor's will. But he clarifies that such an infringement does not constitute a wrong, because of the motive behind the response. The thought appears to be that in order for an action to be wrong, it must not only involve denying the will of another but must also stem from a certain motive. This is just what we would expect from someone who holds that 'in themselves, all deeds are just empty images that acquire moral significance only by virtue of the disposition [Gesinnung] that produces them' (WWR 1:436).

Schopenhauer casts additional light on his view when he describes the act of wronging as the denial of another's will 'with the aim of a stronger affirmation of one's own' (WWR 1:400). Similarly, in his discussion of the virtue of righteousness [Gerechtigheit], that is, the disposition not to wrong others, he claims that the righteous [gerecht] person will not inflict suffering on others 'in order to enhance his own well-being' (WWR 1:437) and that the essence of righteousness, its innermost being, lies in the intention [Vorsatz] 'not to affirm one's own will to the point where it negates other appearances of the will by forcing them to serve one's own' (WWR 1:438). ${ }^{6}$ What Schopenhauer appears to be getting at in these remarks is that impeding the will of another wrongs that individual just in case it is motivated by something like a desire to elevate one's own aims or interests above those of the other, to affirm one's own will over that of the other. To put the point in slightly different terms, we may say that on Schopenhauer's view, an encroachment constitutes a wrong if (and only if) it implies that the encroacher assigns greater importance to her own well-being than to that of the one on whose will she encroaches.

6. The clause 'to enhance his own well-being' was added in the second edition of WWR, no doubt to clarify that we wrong others not just when we inflict suffering on them, but when we do so from this motive. 
Such encroachments may take one of two basic forms. Schopenhauer gestures toward this when he notes that we feel dissatisfaction with our actions not simply because we have acted egoistically, but because 'we have acted too egoistically, with too much regard for our own well-being and too little for that of others, or because we have indeed made into our ends the woe of another for its own sake without advantage to ourselves' (BM 173-74). Accordingly, a wrongful encroachment may stem from what he calls 'extreme egoism' [äußerster Egoismus] (BM 200), which involves pursuing one's own ends without proper regard, or even with deliberate disregard, for others. ${ }^{7}$ Even worse, it may be an expression of spite [Gehässigkeit], malice [Bosheit], Schadenfreude, or the like, in which the mistreatment of another is not the means to one's end, but the end itself.

Returning to the case of self-defense, we can now offer a better explanation of why, on Schopenhauer's view, it is not wrong to ward off an attack even through violent means. Suppose $A$ attacks $B$, either through violence or cunning, and $B$ defends herself against this attack. If $B^{\prime}$ s response is not out of proportion to the threat, then there is nothing about this response that implies that $B$ is attempting to affirm her own will above that of $A$, or in other words, that she intends to elevate her aims above those of $A$. At most it implies only that she regards them as equal. Thus, her defensive response would not be wrong, even though she might injure $A$ 's body, person, property, or honor. On the other hand, suppose that $B$ 's response to $A^{\prime}$ s attack were out of proportion. For instance, suppose $B$ responded to $A^{\prime}$ 's threat to insult her in public by killing $A$. On Schopenhauer's view, this response would indeed wrong $A$, even though $B$ acted in self-defense. For by ending $A^{\prime}$ s life in order to protect her reputation, or in other words, by causing grievous injury to $A$ in order to prevent slight injury to herself, $B$ clearly esteems her own well-being more highly than $A^{\prime}$ s. Similarly, any case of wrongdoing would involve a similar kind of elevated sense of self-importance on the part of the one doing wrong.

The motive component of Schopenhauer's account also allows us to see why, on his view, a person who inadvertently thwarts the will of

7. Cf. Jacquette 2005: 224: 'The idea is that an egoistic action that thwarts another individual's pursuit of his or her interests is morally objectionable'. Properly speaking, such an encroachment is morally objectionable only if it stems from malice or an excessive or exaggerated egoism (cf. Cartwright 1999: 272-73). Accordingly, if in the bare pursuit of one's own self-interest one were to inadvertently thwart the will of another, no wrongdoing would occur. 
another does not thereby wrong that individual. For in such cases there is clearly no intention to elevate one's own aims or interests above those of the other.

\section{Degrees of Consciousness}

The other nuance in Schopenhauer's account of wrong stems from his belief that conative beings have different degrees of sensibility. Roughly put, he holds that a creature's capacity for suffering correlates with the sophistication of its mental life. So, while lower animals such as insects would have a relatively limited capacity for suffering, higher animals such as dogs, pigs, and whales would have a greater capacity, and humans a still greater capacity. ${ }^{8}$ This difference leads Schopenhauer to conclude that even apart from cases of self-defense, a human can sometimes use or take the life of an animal without thereby wronging the animal and thus without doing wrong. As he explains in a footnote with strong consequentialist undertones,

[B]ecause suffering increases along with the increase in the clarity of consciousness, the pain that animals suffer in death or work is not as great as that which humans suffer by doing without meat or animal power. This is why people can affirm their existence to the point of negating the existence of an animal, and the will to live as a whole suffers less than if we acted the other way around. This also determines the extent to which people can make use of animals without doing wrong .... (WWR 1:440n)

Here Schopenhauer admits that it is not necessarily wrong for humans to kill or use animals, even though doing so obviously thwarts the animal's will and even involves intentionally elevating the human's well-being above that of the animal. He offers the rationale that because humans have a greater capacity for suffering, their use of animals sometimes leads to less suffering overall-less suffering on the part of the will to live on the whole, as he puts it-than would otherwise occur. The suggestion therefore appears to be that in order for $A$ to wrong $B, A$ must infringe on $B^{\prime}$ s will in a way that does not lead to less overall suffering than would have occurred had $A$ not so infringed. From this point of view, if one human were to kill and eat another in order to survive, this being the only way to avoid starvation, this killing may well be wrong, since it would

8. On the diminished capacity for suffering in animals, see WWR 1:365-66; WWR 2:64-65; WN 76-77; BM 245, 253; PP 1:337n./SW 5:358n. 
produce no net decline in the suffering of the will to live on the whole. But if a human were to kill and eat an animal under analogous circumstances, this would not be wrong, because the will to live would suffer more if the human were to starve to death than it would if the animal were to be killed. Similarly, if horses were used to transport a severely injured human to the hospital, the intent being not to harm the horses but to help the human, this too would involve no wrong, since the small amount of suffering the horses would experience would be more than compensated for by the reduction in the amount of suffering experienced by the human. Yet Schopenhauer is clear that there are limits to this. For instance, he mentions that we often wrong animals when it comes to our treatment of 'beasts of burden' and hunting dogs. He also considers vivisection, especially on higher animals, to be wrong (WWR 1:140n; cf. PP 2:37377/SW 6:396-401). Similarly, he maintains that when human survival does depend on killing animals for food, we should at least make their death as painless as possible, for instance, by using chloroform (BM 245; PP 2:37576/SW 6:399). ${ }^{9}$ The thought appears to be that in all such cases, our infringements result in more, not less, overall suffering, and consequently we wrong the animals.

In tying the wrongness of an action to its effect on the overall amount of suffering in the world, Schopenhauer may appear to be espousing a kind of consequentialism. But this is almost surely not his intent, since he maintains that the moral worth of an action stems from the motive [Motiv], or more accurately, the incentive [Triebfeder] from which it springs, not from the consequences it produces: from its cause, not its

9. Schopenhauer remarks that 'by abstaining from animals as food, humans, especially in the north, would suffer more than would the animal through a quick and even unforeseen death, which perhaps should be alleviated even more by means of chloroform' (BM 245). Of course, this by no means constitutes an endorsement of the modern practices of intensive animal farming, which he doubtless would have viewed with disdain, much as he viewed vivisection. In fact, given the remarkable developments of the last 150 years in plant agriculture, food production, transportation, and other such areas, a much greater proportion of the human population can now survive and even thrive without relying on animal products and by-products, even in places like Germany. Thus, one imagines that if Schopenhauer were alive today, he might well advocate the widespread adoption of a vegetarian or perhaps even a vegan diet. Cf. PP 2:37576/SW 6:399. On Schopenhauer's advocacy on behalf of animals, see Libell 1998. 
effect. ${ }^{10}$ It would therefore be rather out of character for him to suggest that the moral wrongness of an action derives from its failure to minimize aggregate suffering. A more likely hypothesis is that Schopenhauer wants to link the motive of a wrong action in some way with the degree to which the will to live suffers on the whole. We have so far said that on his view, $A$ wrongs $B$ when $A$ affirms her will so far as to deny the will of $B$, or more precisely, when $A$ infringes on the will of $B$ with the intent of elevating her own aims above those of $B$. But given the moral significance he assigns to differences in capacity for suffering, this cannot be quite right. For if $A$ has a greater degree of sensibility than $B$, then it is not necessarily wrong for $A$ to deny the will of $B$. $A^{\prime}$ s denial only becomes wrong when it goes too far, that is, when $A$ affirms her will at the expense of $B^{\prime}$ s in a way that is out of proportion with the difference between $A^{\prime}$ s degree of consciousness and that of $B$. So a more accurate statement of Schopenhauer's account would be that $A$ wrongs $B$ just in case $A$ denies the will of $B$ with the intent of affirming her own will to a degree that is out of proportion with the degree to which $A^{\prime}$ s capacity for suffering outstrips $B^{\prime}$ s.

A brief consideration of a few examples will confirm that this account accords nicely with Schopenhauer's claims about wrong action. In the first place, in all the cases where one human injures another through assault, insult, or theft, though not in self-defense, it will follow that the first does wrong the second, because the one acts with the intention of elevating her aims above those of the other, even though the two have a (roughly) equal capacity for suffering. ${ }^{11}$ But for the reasons already noted, if a human who

10. In Schopenhauer's terminology, motive (Motiv) is a cognized end that calls forth an action by stimulating an incentive or driving force (Triebfeder) (cf. BM 210), the latter being something like an aspect or disposition of the agent's character or will. The four basic motives or ends of action are (1) one's own well-being, (2) another's well-being, (3) another's woe, and (4) one's own woe (BM 227; cf. WWR 2:695n). Corresponding to the first three motives are the three fundamental incentives relevant to morality: egoism, compassion (Mitleid), and malice (BM 210). Though Schopenhauer does sometimes appear to suggest that the moral worth of a praiseworthy action derives from the motive (cf. BM 134, 204, 207-8), I agree with an anonymous referee that, on Schopenhauer's considered view, moral worth derives from the agent's character, specifically, the incentive of compassion.

11. Schopenhauer acknowledges that even among humans 'clarity of consciousness has innumerable degrees, namely from the dullest, empty mind to the genius' (WN 76-77). Given what he says elsewhere, this appears to commit him to the view that not all humans are morally equal and that under some 
is under attack from another human defends herself with an appropriate degree of force, this would not be a case of wronging, since in defending herself she does not intend to elevate her aims above the other's. Next, in the case of humans using animals for food or labor, this would be justified under limited circumstances. If a human has no alternative source of nourishment, and kills an animal in order to survive, this would not be wrong, since the human would not be esteeming her own well-being to an exaggerated degree. However, if a human were to, say, subject an animal to cruelty in order to derive a small degree of amusement, this would indeed be wrong by the standard of this account, because in valuing a small degree of amusement more highly than the intense suffering of an admittedly lesser animal, the human would be exaggerating the significance of her own aims relative to those of the animal. The same would be true, at least by Schopenhauer's lights, in cases of vivisection and the excessive exploitation of the labor of animals.

\section{Rights}

Having now arrived at what I take to be Schopenhauer's fully nuanced account of wrongdoing, we can turn to the issue of rights. I have said that on his view, the idea of a right, as something which can be possessed, grows out of the notion of wronging. It does so in something like the following way. The idea that we sometimes wrong one another, and thus that our actions are sometimes wrong, leads to the idea of a right action as any action that does not wrong another. This in turn leads to the idea of $a$ right as the ability to do something, or to take or use something, without wronging anyone. Thus, a person can be said to have a right to breathe air, to be on public lands, to admire the starlit sky, and so forth, because none of these actions would wrong anyone. Similarly, I have a right to defend myself against some act of violence or cunning because, in accordance with what has already been said, such a response would not wrong my attacker (or anyone else). But I do not have a right to do anything that would wrong another. So I do not have a right to assault, steal, trespass, or insult, though in the case of animals, Schopenhauer thinks, we humans do

circumstances, a person can elevate her aims above another's, denying the will of the other in the process, without thereby wronging that individual. However, it may be that the differences in degree of consciousness among humans are relatively small compared to those between humans and animals, and that for nearly all practical purposes, humans can be regarded as equal with respect to their capacity for suffering. 
have a right to kill and use them up to a point. This basic sense of a right corresponds to what Hohfeld (1919) calls a privilege and others more appropriately call a liberty.

Schopenhauer sometimes gives the impression that on his view, all rights are liberties in this sense. For example, he remarks that 'human rights [Menschenrechte] are easy to determine; everyone has the right to do that which injures no one' (PP 2:241/SW 6:257). But clearly there are more rights on his view than just liberties. For when he chides other philosophers for denying that animals have rights, his point cannot be merely the trivial thought that animals can do many things without wronging others. His point is rather that animals can be wronged, that our conduct toward them has moral significance, even apart from its bearing on ourselves and other humans. He contrasts the view that animals have rights with the belief that animals are mere things with which we can do as we please. Likewise, he equates the view that they lack rights with 'the delusion that our actions toward them are without moral significance' (BM 238). Obviously the rights he has in mind in these contexts concern not what can be done without wronging another, but what cannot be done by others without wronging the right-holder. To have a right in this sense is just to be capable of being wronged, as when we say, for instance, that a person has a right to humane treatment, because to treat her otherwise would be to wrong her. These rights correspond roughly to what, following Hohfeld, we now call claims. More precisely, they are negative claims, since they concern not the provision but the withholding of something, namely, the interference of another.

In addition to liberty-rights and negative claim-rights, Schopenhauer also recognizes the existence of positive claim-rights. Unlike negative claims, which are general in the sense that they express facts about the right-holder's relationship to all moral beings or at least all moral agents, positive claims are those which arise because one or more moral agents enter into an agreement with the right-holder. Thus, if $A$ enters into an agreement with $B$ to provide the latter with some good or service, but then reneges on the agreement, $A$ wrongs $B$. So in accordance with the idea of a right as the negation of a wrong, Schopenhauer recognizes that the agreement between $A$ and $B$ endows $B$ with a right to the promised good or service from $A$. This right is a claim because it expresses what $A$ cannot do, or rather cannot fail to do, without wronging $B$. But since it is a right to the provision of something positive (i.e., the good or service) rather than to the absence of something positive (i.e., interference), the right is positive. $B^{\prime}$ s right is therefore a positive claim. 
Rights are often said to correlate with duties. For Schopenhauer, matters are not so simple. As he sees it, philosophers such as Kant have enlarged the concept of duty well beyond its proper sphere, with the result being that we are said to have many duties, such as a duty to help others, which we could often fail to perform without actually wronging anyone. In contrast, Schopenhauer maintains that a duty, properly speaking, is simply any action which one cannot decline to perform without wronging another (BM 220-22). So, for instance, in our previous example, $A$ does have a duty to provide $B$ with the promised good or service, because if $A$ were to fail to provide that service, then $A$ would be wronging $B$. But $A$ does not have any duty to help others in general, since to withhold help from them would not be to wrong them, even if it might be cruel and repugnant (WWR 1:400). ${ }^{12}$ From this point of view, the only duties or obligations one has are those which arise from agreements. When $A$ enters into the agreement with $B, A$ assumes a duty and $B$ acquires a right. Furthermore, since such agreements always involve a mutual exchange of goods or services $-A$ agrees to provide $B$ with the good or service only because $B$ agrees to provide something in return $-B$ also assumes a duty and $A$ also acquires a right. Thus, if I were to contract with Fred to mow my lawn for the tidy sum of twenty dollars, then I would thereby acquire a right to Fred's service, while he would undertake a duty to provide that service. At the same time, he would acquire a right to be paid twenty dollars upon mowing my lawn, while I would undertake a duty to pay him. We may therefore say that on Schopenhauer's view, even though rights do not in general correlate with duties, positive claims do correlate with duties.

Schopenhauer maintains that an individual's specific rights typically arise from an explicit, mutual agreement. He does, however, recognize one important exception to this general rule. The problem with taking the rule to be exceptionless is that if it were, parents would have no duty or

12. Some critics have suggested that if animals had rights, we would have an obligation to prevent natural predation (Ritchie 1895: 109-10; Warren 1997: 11114; cf. McCloskey 1965: 123). On Schopenhauer's view, however, this does not follow. Though intervening to prevent one animal from killing another might, under some circumstances, be compassionate and thus morally good, not doing so would not thwart anyone's will, thus would not wrong anyone. Since we have a duty or obligation to perform only those actions the omission of which would wrong someone, it follows that we have no duty to prevent or discourage natural predation. 
obligation to provide for their young children, who are incapable of entering into agreements. Now many versions of contractarianism may indeed have this consequence. ${ }^{13}$ But Schopenhauer is not willing to go so far. He recognizes that if his view is to be plausible, he must make room for the possibility of a person undertaking a duty even apart from a mutual agreement. He therefore allows that in the case of a parent's duty to care for her child, that duty 'is not taken on by means of an agreement, but immediately through mere action, because those to whom one has this obligation were not present when it was undertaken' (BM 221). What Schopenhauer appears to be suggesting is that, even though in the typical case one assumes a duty through an explicit, mutual agreement, all that is really needed to generate this sort of duty is that one make a commitment to another individual to provide them something. In the case of the parent, this commitment is not typically an explicit one but is made implicitly by the mere fact of voluntarily bringing the child into existence, giving birth to it, or the like. ${ }^{14}$

To summarize: Schopenhauer understands rights as in one way or another negations of wrong. Some rights express those actions that we can do without wronging anyone, while others express those actions that others cannot do, or fail to do, without wronging the right-holder. Among the latter, only those which concern what others cannot fail to do without wronging correlate with duties, in the proper sense of the term. So any being that is capable of acting without wronging others has rights in the first sense, and any being that is capable of being wronged has rights in the second. Finally, anyone to whom something has been promised has a right to that thing, while the promiser has a duty to provide it.

\section{Animal Rights}

It should now be a fairly straightforward matter to see why Schopenhauer accords rights - specifically, claims - to animals. We have seen that on his analysis, to have a right in this sense is just to be capable of being wronged. The question, then, is whether animals can be wronged; and on his analysis, it seems clear that they can. For in order to be capable of

13. On the difficulty of grounding parental obligations within a contractarian framework, see Eekelaar 1991.

14. Here I take Schopenhauer to be endorsing a voluntarist account of parental obligation akin to the one defended recently by Brake (2010), rather than a merely causal account such as those of Archard (2010), Prusak (2013), and Porter (2014). 
being wronged, it suffices that one have a will that can be thwarted, where by 'will' Schopenhauer does not mean anything particularly advanced. He certainly does not have in mind the Scholastic conception of will as a rational appetite. Nor does he have in mind something which requires beliefs, knowledge of a language, or a concept of self. Rather, for him, will (in this sense) refers simply to a conscious appetite or desire, something which at least many animals, including most vertebrates and even some invertebrates, can plausibly be supposed to possess. ${ }^{15}$ Hence, it follows that many animals have rights in this sense. ${ }^{16}$ For instance, they have rights not to be treated cruelly, not to be exploited for our amusement, not to be killed or caused to suffer unnecessarily, and so forth. ${ }^{17}$ In all such cases, we wrong them by affirming our own wills so far as to deny theirs in a way that outstrips the degree to which our capacity for suffering exceeds theirs.

The conclusion that animals have rights in this sense is significant because it means that, contra Kant and most of the Western philosophical tradition, our conduct towards them does have moral significance, even apart from its bearing on ourselves. ${ }^{18}$ It means, for example, that it is wrong, and thus immoral, for us to cause them great harm for the sake of amusement or convenience; and this not because of what it does to us, but because of what it does to them. To affirm this much, however, is not to suggest that it is always wrong for us to use or kill animals. For the same analysis of moral rights which justifies ascribing them to many animals (and most humans), also reveals that those rights do not have the

15. For substantiation of this claim, see DeGrazia 1996: 129-43; Varner 2002: 2654; Carruthers 2011: 378-82. According to Carruthers, empirical evidence warrants the conclusion that mammals, birds, and navigating invertebrates (including bees, wasps, and spiders) all have desires or goals that are capable of being frustrated.

16. Carl Cohen (1997: 95; Cohen and Regan 2001: 30-31) maintains that in order to possess rights, one must be capable of doing wrong; and on this basis he denies that animals can have rights. From Schopenhauer's perspective, however, Cohen's reasoning is confused. The question is not whether animals can wrong, but whether they can be wronged.

17. In addition to vivisection, Schopenhauer mentions coursing, bullfighting, horse-racing, and whipping draft animals to death (BM 162), as well as chaining up dogs and caging birds (PP 2:376-77n/SW 6:398n), as examples of shameful practices.

18. On Kant's view of animals, see Korsgaard 2011, especially §5. 
abolitionist implications they have often been thought to have. ${ }^{19}$ From the perspective of this analysis, many animals have various rights. But they do not have a right to life or to non-interference that makes it always wrong to kill or use them. As we have seen, there can be circumstances under which humans can kill or use animals without wronging them, and thus without violating any rights. The possession of rights by animals does not, therefore, entail that we cannot rightly kill them for food, experiment on them, and so forth. Rather, it entails only that there are limits to the circumstances under which, and reasons for which, we can treat animals in such ways without being immoral.

When Schopenhauer speaks of animals having rights, he no doubt has in mind the kind of negative claims just mentioned. But I would like to call attention to three other kinds of rights which he does not ascribe to animals, but which he appears to commit himself to ascribing to them. The first is liberties. On Schopenhauer's account, one has a right in this sense, that is, a right to $\varphi$, just in case one can $\varphi$ without wronging another (see §5). But it would appear that animals can do many things without wronging others. In fact, though Schopenhauer does not say this, it is tempting to think that animals are entirely incapable of wronging others. To be sure, they do affirm their own wills, and in the process they sometimes deny the will of another. But the animal's denial of another's will is always incidental. If one animal kills another, or even a human, the impetus is always some basic appetite such as hunger, an emotion such as fear, or perhaps playfulness or curiosity, but in any case not a malicious or excessively egoistic desire to elevate one's own aims above those of another. Indeed, Schopenhauer explicitly denies that animals have intention (Vorsatz), which on his account is necessary for wrongdoing (WWR 2:65). It would therefore seem that on his view, animals can do no wrong, and thus have a right, in this sense, to do anything they are capable of doing. This also explains why it makes no sense to speak of animals violating the rights of other. Even if they act in ways that impede the will of another, they lack the kind of complex, self-exalting intention required for wrongdoing.

Second, Schopenhauer's view appears to imply that animals can have property rights. As I noted in $\$ 2$, he endorses a labor-mixing theory according to which any natural resource that is not already owned

19. The assumption that rights must have abolitionist implications has led at least one scholar (Jones 1991: 131) to conclude-mistakenly, and despite clear evidence to the contrary - that Schopenhauer denies rights to animals. 
becomes the property of the one who labors on it in the form of either improving it or protecting it from harm. But this seems to be exactly what happens, for instance, when beavers build a dam or a bird builds a nest. In contrast with Locke (1689: $\S \S 25-26)$, who appears to limit the class of those who can acquire property to those to whom God has given all things in common, that is, humans, Schopenhauer's account of property includes no such qualification. Animals certainly seem capable of mixing their labor with natural resources, and in doing so, they often 'improve' them, for example, by taking scattered sticks and forming them into a nest. In some cases they even protect their nests and the other fruits of their labor from harm. Hence, it seems to follow on Schopenhauer's account that animals can acquire property and thus can have property rights. ${ }^{20}$ In particular, they would have a right not to have their property damaged or taken by humans in a way that would wrong them. Thus, although disturbing the property of an animal would not be inherently wrong, it would be wrong, thus would violate the animal's right, under many circumstances, as for example if we were to destroy a beaver dam for the sake of amusement or a small degree of convenience.

The third type of animal right to which Schopenhauer appears to have committed himself is positive claims resulting from commitments that particular humans make to care for certain animals. We have seen that on his view, parents assume a duty to care for their child by the mere act of bringing that child into existence, while the child acquires a correlative right to that care. But if this be admitted, then it becomes difficult to see how Schopenhauer can avoid applying this sort of reasoning more broadly. In the first place, it seems not to matter whether the child is one's biological offspring or adopted. In the former case, the parents assume the duty 'immediately through a mere action' (BM 221), presumably the act of conceiving, the decision to carry the pregnancy to term, the act of giving birth, or something along those lines. But the act of agreeing to adopt a child would seem to be just as efficacious in generating a duty. If the act of conceiving generates a duty to care for the resulting child, why would the act of agreeing to adopt a child not likewise generate such a duty? In the second place, it now seems as if consistency requires Schopenhauer to admit that any act through which one knowingly brings another into being or even takes another under one's wing, as it were, suffices to generate an obligation, that is, a duty, to care for the other so long as that

20. For a similar point, though made in connection with Locke's account of property, see Rachels 1989: 124-25. 
care is needed. But this has far-reaching implications, particularly for animals. For it implies that if a human adopts a companion animal such as a cat or dog, she thereby assumes a duty to care for that animal as long as the care is needed. ${ }^{21}$ Similarly, it implies that anyone who participates in animal husbandry, or who otherwise breeds and raises animals for some purpose, would likewise have a duty to care for those animals. So, for example, the dairy farmer would have a duty to care for the cows she raises for milk production, as well as the offspring who are generated as a by-product of that process. Hence, Schopenhauer's position on duties seems to commit him to the view that many humans have duties to care for particular animals, and thus that many animals have the correlative rights to that care from those humans.

\section{Philosophical Significance}

Having now completed my reconstruction of Schopenhauer's case for animal rights, I want to conclude by calling attention to three respects in which his account compares favorably with views that have been advanced by rights-theorists in recent decades.

The first concerns Schopenhauer's distinctive conception of moral or 'pure ethical' rights, as he calls them (BM 218). Rights of this sort are commonly supposed to have a special normative force by which they impose absolute or at least very strong constraints on our conduct. ${ }^{22}$ But for this very reason they have also raised suspicion among many philosophers, especially those of a utilitarian cast of mind..$^{23}$ The worries here have varied, but Frey (1980: 8-17) captures one central concern nicely when he argues that these rights are either doubtful or superfluousdoubtful if the constraints they allegedly generate cannot be derived from our considered moral principles, and superfluous if they can. In contrast, Schopenhauer articulates a conception of moral rights that renders the existence of such rights relatively uncontroversial. On his analysis, rights are simply expressions of that which is, in one way or another, not wrong.

21. For a recent development of this theme, see Burgess-Jackson 1998.

22. See, e.g., the characterizations of rights as trumps over the interests of the many (Dworkin 1977: 364-68; Dworkin 1984; Cohen and Regan 2001) or as inviolable constraints on our actions (Nozick 1974: 29-33).

23. Early critics of moral or natural rights include Burke (1790), Bentham (1843), and Ritchie (1895). The many recent examples include Nelson (1976), Young (1978), Frey (1980; 1983), Singer (1987), and Foreman (2015). 
In the most important case, that of claims, a right expresses what cannot be done to the right-holder without wronging that individual. Hence, to affirm rights in this sense is simply to endorse the thought that some individuals, human or otherwise, can be wronged, and indeed, can be wronged independent of any positive law (BM 218). To be sure, this thought is not entirely above reproach. For instance, some moral skeptics may well deny that there is any such thing as wrongdoing. Others may allow that people can be wronged, though not apart from positive law. On the whole, however, the claim that at least some individuals can be wronged, even apart from positive law, would seem to be relatively uncontroversial, even among philosophers. Moral rights in Schopenhauer's sense should therefore raise few objections.

To the extent that this is an advantage of Schopenhauer's account, it is one he purchases at what some may consider an unacceptable expense, namely, the loss of the special normative force that lies at the heart of the usual conception of rights. On his view, rights do not impose any additional constraints on our actions, that is, in addition to those imposed by the principle that it is immoral to wrong someone. So the first horn of Frey's dilemma does not apply. What about the second? For Schopenhauer, rights-talk is simply a convenient way of talking about ways of not wronging. The concept of wrong does all the heavy lifting. In fact, all use of 'right' and its cognates could be eliminated from his moral theory and that theory would still be complete. Whatever one might have been tempted to express in terms of rights could simply be put in terms of not-wronging. In this sense there is a grain of truth in the charge of superfluity. Yet whatever we might say about the language of rights, it is important to see that the concept of rights plays a critical role in Schopenhauer's thought. For without it we would lose the morally important category of actions that can or cannot be done without wronging others.

One thought which may have occurred to the reader by now is that Schopenhauer's approach, though couched in the language of rights, is actually closer in spirit to consequentialism than to what we have come to think of as rights-based approaches. After all, one who possesses rights in his sense can still be rightfully killed, restrained, used, and so forth, as long as the incentive for so doing is concern or love for others and not excessive egoism or malice toward the right-holder, just as on a consequentialist approach, it is not wrong to treat others in such ways if doing so produces the best consequences. In response, I concede that the thought is true, at least in one important respect: both Schopenhauer and 
the consequentialist deny that actions have any moral worth in themselves. It should be noted, however, that Schopenhauer's view is actually even closer to a virtue-theoretic approach. Indeed, it is a virtuetheoretic approach, insofar as it locates the moral worth of an action not in the action itself or its effects, but in its cause, namely, the motive or incentive from which it flows. ${ }^{24}$ His theory can accordingly be viewed as an account of how to think about rights within a broadly virtue-ethical framework. ${ }^{25}$

Moving on, the second significant feature of Schopenhauer's account is that it establishes a clear and intelligible connection between the concept of a right and a criterion for the possession of rights. This is significant because other rights-theorists have struggled to do this. Typically they have left the connection at an intuitive level, with the result being that even those who share the same basic understanding of the nature of rights have arrived at different criteria for their possession. For instance, among those who define rights as valid claims, various extensionally divergent criteria have been proposed: being human (Cohen 1997; Cohen and Regan 2001: 30-38), having interests (Feinberg 1974), having inherent value (Regan 2004), and so forth. Yet the authors of these proposals have cast little light on the connection between the idea of a valid claim and their preferred criterion. The point can be illustrated in another way by considering the views of $\mathrm{H}$. J. McCloskey. In his earlier treatment of the subject, he maintains that rights, as 'entitlements to do, have, enjoy or have done' (1965: 118), can be possessed only by those who have interests, which he denies to animals (ibid.: 126). On this basis, he concludes that animals cannot have rights. However, he admits that the concept of interest is 'an obscure and elusive one' (ibid.), and he offers no clear explanation of the connection between a right, so conceived, and the possession of interests. Now fast-forward fourteen years. In some fuller and more mature reflections on the topic of animal rights, McCloskey admits that his earlier arguments were 'mistaken, misconceived, and misdirected in quite a number of ways' (1979: 36). One of these mistakes was 'linking interests and the having of interests, with the having of the

24. Cf. n. 10. On Schopenhauer's view as a kind of virtue ethics, see Atwell 1990: 67-142, and Cartwright 1999. For a recent defense of a motive-centered approach to ethics, see Slote 2001.

25. Virtue ethicists have tended to eschew the concept of rights. See, for instance, Hursthouse 2006 and Hursthouse 2011. 
capacity to be a bearer of rights' (ibid.: 37). He now admits that he sees no convincing argument to this effect, and he dismisses the arguments of Leonard Nelson (1956), a pioneer of this view, as 'only the flimsiest of arguments, definitional fiats rather than genuine arguments' (ibid.: 37-38). Instead, he now proposes that rights belong to just those beings who exercise 'moral autonomy', that is, 'a capacity to act and to decide to act on the basis of a moral evaluation of the alternative possible actions' (ibid.: 31, 41). (Not coincidentally, McCloskey also reverses course on the issue whether animals have interests. He now admits that they do, though he still denies them rights, since they fail to satisfy the newer, stronger criterion.) But what is the connection between rights, still understood as entitlements to do or have, or to not have done or taken, and this sort of moral autonomy? In essence, McCloskey's thought is that such entitlements can properly be ascribed only to those who are themselves capable of demanding or waiving that to which they are entitled, or who would so act if they did possess such capacities (ibid.: 29-30). But what is the connection between rights, so conceived, and this sort of capacity? Unfortunately, McCloskey leaves this at an intuitive level. In the end, his case for this new criterion is just as much a matter of definitional fiat as Nelson's.

The point I want to make about Schopenhauer's account is that, by offering a deeper analysis of the concept of a right (that is, deeper than the bare idea of an entitlement or valid claim), he succeeds in establishing an intelligible connection between that concept and a criterion for the possession of rights. As we have seen, he analyzes rights in terms of wrong, and the latter in terms of a kind of thwarting of the will of another. Thus, it follows that rights, at least in the sense of claims, belong to just those beings who have a will that is capable of being thwarted, that is, who have a will. From this point of view, the correct criterion for the possession of rights is not humanity, rationality, inherent value, the possession of interests, or what have you; rather, it is simply that of having wishes, desires, appetites, or any of those conscious, conative states that can be grouped under the general term will. ${ }^{26}$

26. Feinberg (1974: 52; cf. 49-50) maintains that interests 'are compounded out of desires and aims'. This might appear to bring his interest criterion into line with Schopenhauer's volitional criterion. However, Feinberg also claims that desires and aims 'presuppose something like belief, or cognitive awareness' (ibid.: 52), and even though he notes that many higher animals seem to be among the kinds of beings who can have rights (ibid.: 50), one might well doubt whether they 
As before, I do not mean to suggest that Schopenhauer's criterion is above reproach. One might well question his analysis of wrong, and in the process call that criterion into doubt. For instance, one might hold that wronging is always the violation of a mutual agreement, thus restricting rights to those who have entered into, and hence are capable of entering into, such agreements. It is not my intent here to argue that Schopenhauer's analysis of wrong is the correct one, though I do consider it plausible. The more modest point I am making is just that by analyzing right and wrong as he does, Schopenhauer accomplishes what many other rights-theorists have failed to do: namely, establish an intelligible connection between the concept of a right and a particular criterion for the possession of rights.

The third significant feature of Schopenhauer's account is that the criterion for rights-possession it generates has a fairly straightforward application to the case of animals. This advantage cannot be claimed by all such criteria. For instance, the suggestion that rights belong to all and only those with interests has spawned a vigorous debate about whether animals possess interests in the requisite sense (McCloskey 1965; Feinberg 1974; Frey 1980). Likewise, Regan's idea that at least many animals have inherent value, and thus have rights, has raised serious doubts (Cohen 1997: 100-1; Cohen and Regan 2001: 52-55, 246-54; Rowlands 2009: 86-97). But whatever doubts we might have about whether animals possess interests or inherent value, it seems clear that at least many animals, including nearly all well-formed, adult vertebrates, have a will in the basic sense Schopenhauer requires for being capable of being wronged. Indeed, as I noted above (n. 15), Carruthers (2011: 378-82) has argued on the basis of empirical evidence that not only mammals and birds, but even navigating invertebrates such as bees, wasps, and spiders, all have desires or goals that are capable of being frustrated. ${ }^{27}$

have beliefs in the requisite sense (cf. Frey 1980: 55-59, 111-18). On Schopenhauer's view, in contrast, an animal need not be supposed to have beliefs in order to be said to have a will and thus rights.

27. See also DeGrazia 1996: 129-43; Varner 2002: 26-54. Carruthers (2005: 177-94; 2011: 375-77) also argues that this sort of desire frustration constitutes psychological harm and, as such, is the proper object of our sympathy. In this respect, his view bears a striking resemblance to Schopenhauer's, though his contractarian moral theory leads him to rather different conclusions about the rights and more generally the moral status of animals (cf. Carruthers 1992; 2011: 385-401). 
In view of these points, I conclude that there is much of value in Schopenhauer's distinctive approach to rights. He articulates a notion of moral right that should be acceptable to most philosophers, even many of those who object to moral rights as they are usually understood. His analysis also establishes a clear and intelligible connection between the concept of a right and a criterion for the possession of rights, namely, that of possessing a will. Finally, this criterion allows us to say with some confidence that at least many animals do have rights in this sense. In sum, he offers a way of thinking about moral rights that makes it plausible to believe that there are such rights, that at least many animals possess them, and consequently that, given our motives, many of the ways we treat them violate these rights and thus are immoral. In many ways, this account represents a promising alternative to the more familiar animal rights positions advanced in recent years.

Stephen Puryear

Department of Philosophy and Religious Studies

North Carolina State University

Raleigh, NC 27695-8103

USA

smpuryear@ncsu.edu

\section{References}

Archard, D. (2010), 'The Obligations and Responsibilities of Parenthood', in D. Archard and D. Benatar (eds.) Procreation and Parenthood: The Ethics of Bearing and Rearing Children. New York: Oxford University Press.

Atwell, J. E. (1990), Schopenhauer: The Human Character. Philadelphia: Temple University Press.

Bentham, J. (1843), 'Anarchical Fallacies', in J. Bowring (ed.) The Works of Jeremy Bentham, vol. 2. Edinburgh: William Tait.

Brake, E. (2010), 'Willing Parents: A Voluntarist Account of Parental Role Obligations', in D. Archard and D. Benatar (eds.) Procreation and Parenthood: The Ethics of Bearing and Rearing Children. New York: Oxford University Press.

Brosow, F. (2008), 'Die beiden Grundprobleme der Schopenhauerschen Tierethik', Schophenhauer-Jarhbuch, 89: 197-219.

Burgess-Jackson, K. (1998), 'Doing Right by Our Animal Companions', Journal of Ethics, 2: 159-85. 
Burke, E. (1790), Reflections on the Revolution in France.

Carruthers, P. (1992), The Animals Issue: Moral Theory in Practice. New York: Cambridge University Press.

--- (2005), Consciousness: Essays from a Higher-Order Perspective. New York: Oxford University Press.

--- (2011), 'Animal Mentality: Its Character, Extent, and Moral Significance', in T. L. Beauchamp and R. G. Frey (eds.) The Oxford Handbook of Animal Ethics. New York: Oxford University Press.

Cartwright, D. E. (1999), 'Schopenhauer's Narrower Sense of Morality', in C. Janaway (ed.) The Cambridge Companion to Schopenhauer. New York: Cambridge University Press.

Cohen, C. (1997), ‘Do Animals Have Rights?' Ethics \& Behavior, 7: 91-102.

Cohen, C. and Regan, T. (2001), The Animals Rights Debate. Lanham: Rowman \& Littlefield Publishers.

Copleston, F. (1947), Arthur Schopenhauer: Philosopher of Pessimism. Andover: Burns Oates \& Washbourne.

DeGrazia, D. (1996), Taking Animals Seriously: Mental Life and Moral Status. New York: Cambridge University Press.

Dworkin, R. (1977), Taking Rights Seriously. Cambridge, MA: Harvard University Press.

--- (1984), 'Rights as Trumps', in J. Waldron (ed.) Theories of Rights. New York: Oxford University Press.

Eekelaar, J. (1991), 'Are Parents Morally Obliged to Care for Their Children?' Oxford Journal of Legal Studies, 11: 340-53.

Feinberg, J. (1974), 'The Rights of Animals and Unborn Generations', in W. T. Blackstone (ed.) Philosophy \& Environmental Crisis. Athens: University of Georgia Press.

Foreman, E. (2015), 'Doing Away with Rights', in E. Aaltola and J. Hadley (eds.) Animal Ethics and Philosophy: Questioning the Orthodoxy. New York: Rowman and Littlefield.

Frey, R. G. (1980), Interests and Rights: The Case Against Animals. Oxford: Clarendon Press.

--- (1983), Rights, Killing, and Suffering. Oxford: Basil Blackwell.

Gebert, S. (2008), 'Mitleid und Interesse. Schopenhauer als halbherziger Vordenker der Tierethik', Schophenhauer-Jarhbuch, 89: 245-65.

Haucke, K. (2008), ‘Der moralische Status von Tieren, oder Lässt sich mit Schopenhauer heute eine Tierethik fundieren', Schophenhauer-Jarhbuch, 89: 221-44.

Hohfeld, W. N. (1919), Fundamental Legal Conceptions. New Haven: Yale University Press. 
Hursthouse, R. (2006), 'Applying Virtue Ethics to Our Treatment of the Other Animals', in J. Welchman (ed.) The Practice of Virtue: Classic and Contemporary Readings in Virtue Ethics. Indianapolis: Hackett Publishing.

--- (2011), 'Virtue Ethics and the Treatment of Animals', in T. L. Beauchamp and R. G. Frey (eds.) The Oxford Handbook of Animal Ethics. New York: Oxford University Press.

Jacquette, D. (2005), The Philosophy of Schopenhauer. Montreal: McGillQueen's University Press.

Jones, K. (1991), 'Schopenhauer on Animals', Schopenhauer-Jahrbuch, 71: $131-42$.

Jones, P. (1994), Rights. New York: Palgrave Macmillan.

Jordan, N. (2010), 'Schopenhauer's Politics: Ethics, Jurisprudence and the State', in A. Neill and C. Janaway (eds.) Better Consciousness: Schopenhauer's Philosophy of Value. Hoboken: Wiley-Blackwell.

Korsgaard, C. K. (2011), 'Interacting with Animals: A Kantian Account', in T. L. Beauchamp and R. G. Frey (eds.) The Oxford Handbook of Animal Ethics. New York: Oxford University Press.

Libell, M. (1998), 'Active Compassion in Schopenhauer's View on Animals', Schopenhauer-Jahrbuch, 79: 113-25.

Locke, J. (1689), Second Treatise of Government.

McCloskey, H. J. (1965), 'Rights', Philosophical Quarterly, 15: 115-27.

--- (1979), 'Moral Rights and Animals', Inquiry, 22: 23-54.

Nelson, L. (1956), A System of Ethics, N. Guterman (trans.). New Haven: Yale University Press.

Nelson, W. (1976), 'On the Alleged Importance of Moral Rights', Ratio, 18: $145-55$.

Nozick, R. (1974), Anarchy, State, Utopia. New York: Basic Books.

Porter, L. (2014), 'Why and How to Prefer a Causal Account of Parenthood', Journal of Social Philosophy, 45: 182-202.

Prusak, B. G. (2013), Parental Obligations: The Duties of a Creator. New York: Routledge.

Rachels, J. (1989), 'Why Animals Have a Right to Liberty', in T. Regan and P. Singer (eds.) Animals Rights and Human Obligations, 2nd ed. Englewood Cliffs: Prentice-Hall.

Regan, T. (2004), The Case for Animal Rights, 2nd ed. Berkeley: University of California Press.

Ritchie, D. G. (1895), Natural Rights: A Criticism of Some Political and Ethical Conceptions. New York: Macmillan. 
Rowlands, M. (2009), Animal Rights: Moral Theory and Practice, 2nd ed. New York: Palgrave Macmillan.

Rousseau, J.-J. (1755/1992), Discourse on the Origin of Inequality, D. A. Cress (ed.) Indianapolis: Hackett Publishing.

Singer, P. (1987), 'Animal Liberation or Animal Rights?' Monist, 70: 3-14.

Slote, M. (2001), Morals from Motives. New York: Oxford University Press.

Varner, G. E. (2002), In Nature's Interests?: Interests, Animal Rights, and Environmental Ethics. New York: Oxford University Press.

Warren, M. A. (1997), Moral Status: Obligations to Persons and Other Living Things. New York: Oxford University Press.

Young, R. (1978), 'Dispensing with Moral Rights', Political Theory, 6: 63-74. 